\title{
STRUCTURAL TRANSFORMATION AND THE AGRICULTURAL FOOD SYSTEM: AN INTRODUCTION
}

Paul Dorosh and Bart Minten

thiopia's agricultural sector has grown rapidly since 2000 due to a dou-

bling in the use of modern inputs (chemical fertilizers and improved seeds), significant land expansion, increased labor use, and a 2.3 percent per year growth in total factor productivity (TFP) (Bachewe et al. 2018). At the same time, there has been a substantial spatial and structural transformation of the economy. Ethiopia's urban population has more than doubled in the past 20 years (from 7.3 million in 1994 to 17.5 million in 2015), and nonagricultural output has grown rapidly so that the share of nonagriculture in GDP has risen from less than half in 2000 to about two-thirds today. Moreover, household welfare indicators have improved dramatically as rural poverty fell from 45 percent in 1999-2000 to 23.5 percent in 2015-2016 (Figure 1.1). Measures of malnutrition of children also improved significantly. For example, from 2000 to 2016 the child stunting rate fell from 58 percent to 38 percent while the share of children that are underweight declined from 41 percent to 24 percent over the same period (Ethiopia, CSA and ICF 2016; NPC 2017) (Figure 1.2). However, wasting only declined by 2 percent.

\section{A Story Too Good to Be True?}

Some skeptical observers have challenged this rapid progress. Did agricultural production really increase that fast? Has poverty actually fallen? Are the gains sustainable? Will further urbanization bring an end to this agricultural growth?

The evidence for substantial agricultural growth is indeed strong, although it is not possible to definitively state that growth has been as high as reported. Ethiopia's fertilizer use per hectare of arable land has increased rapidly and was 2.8 times higher in 2014-2016 than in 1991-1992. The fertilizer use rate in neighboring Kenya was almost unchanged over the same period 


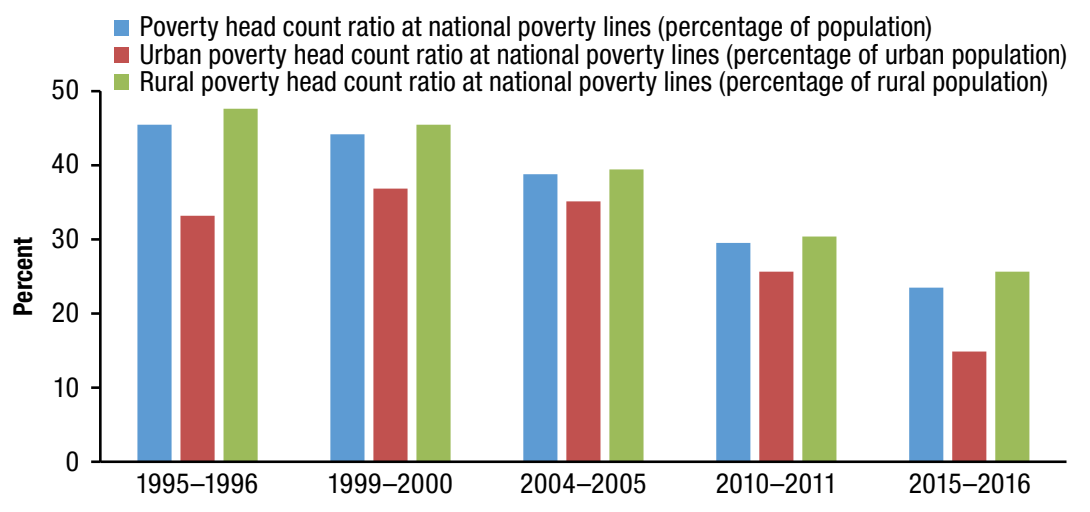

Source: NPC (2017), World Bank (2018), and authors' calculations.

(Figure 1.3). ${ }^{1}$ Average maize yields in Ethiopia in 2015-2017 were 2.63 times those in 1999-2001. In the same period, average maize yields in Malawi rose 53 percent; yields in Kenya fell 11 percent (Figure 1.4). ${ }^{2}$ Area cultivated also increased, as did labor input and use of improved seeds, so that estimated total factor productivity growth (the part of cereal production growth not accounted for by increased inputs) was only 2 percent per year-a high but not implausible figure (Chapter 3; Bachewe et al. 2018). ${ }^{3}$

Trends in real market prices of major cereals provide additional evidence of major gains in production, but likewise they do not suggest exact magnitudes of the size of the production increase. Earlier analysis of the implications of potential production gains for real prices, farmer incomes, and poverty income suggested that high agricultural growth ( 6 percent annual growth in real agricultural GDP) would lead to only moderate declines in real prices of major crops, as long as there was substantial growth in the nonagricultural economy as well (Dorosh and Thurlow 2012). ${ }^{4}$ As shown in Figure 1.5, trend growth of

1 Note that the FAO data presented here on fertilizer nutrients per hectare of arable land up to 2015/2016 corresponds to the definitions used in Figure 3.12A. Figure 3.10, which shows fertilizer use (gross weight) per hectare of fertilized area, indicates a further sharp rise in fertilizer use in Ethiopia in 2016/2017 and 2017/2018.

2 Maize is used as a comparator for cereal yields across countries since it is Ethiopia's main cereal crop by tons of production and is widely grown across much of Africa south of the Sahara.

3 From 2004/2005 through 2015/2016, labor accounted for 34 percent of the 8.3 percent per year output growth; fertilizer 11 percent, improved seeds 10 percent, land 8 percent, and TFP 25 percent (Bachewe et al. 2018).

4 A 6 percent growth rate was the target set as part of the Comprehensive Africa Agriculture Development Programme (CAADP) compact agreed to by Ethiopia and 42 other countries of 
FIGURE 1.2 Trends in nutritional status of children under five years old

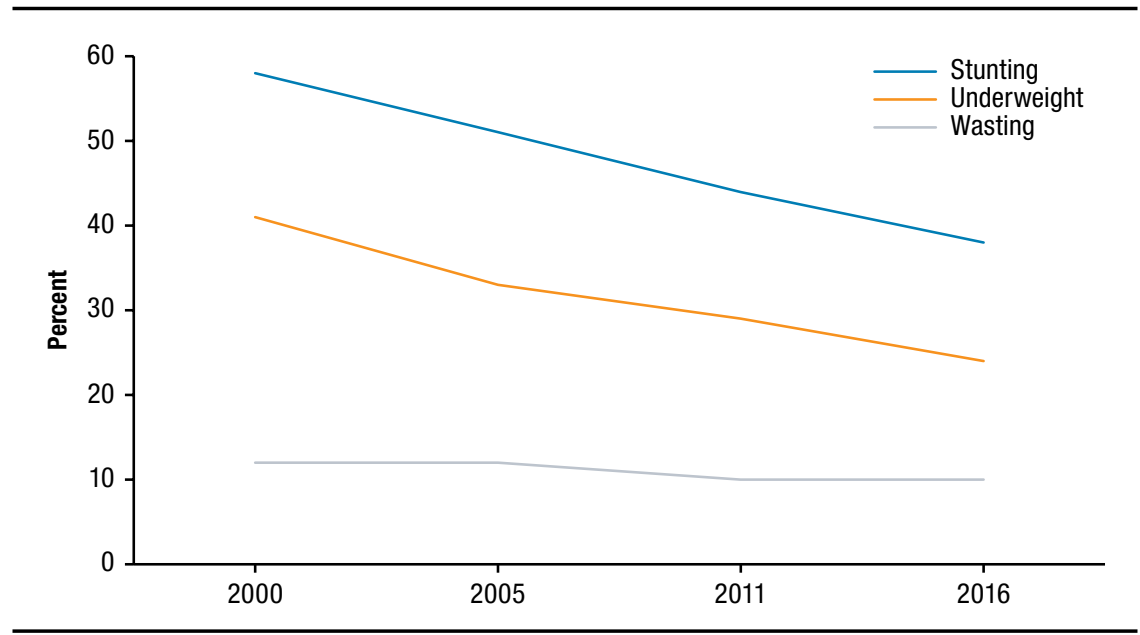

Source: Ethiopia, CSA and ICF (2016).

real prices of teff, wheat, maize, and sorghum has been negative $(-0.2$ percent, -1.5 percent, -2.9 percent, and -3.2 percent per year, respectively), an indication that growth in demand (from population growth, higher per capita incomes, and other factors) has not kept up with growth in supply.

Finally, data on household consumption and nutritional outcomes strongly suggest that there have been significant increases in quantities of food consumed (Chapter 7, Table 7.3) and dietary diversity (Chapter 10, Tables 10.4 and 10.5$)$ that are consistent with both gains in production and improvements in nutritional outcomes cited earlier.

Substantial public investments in agriculture have played a major role in this success. Beginning in the 1990s, the Meles government placed a major emphasis on agricultural growth as a mechanism for growth and poverty reduction. The strategy of agricultural development-led industrialization (ADLI) initiated in the late 1990s saw agriculture as a major engine of overall economic growth through positive growth linkages with food processing and trade as well as through generation of fiscal and foreign exchange resources of increased investment. ${ }^{6}$ Successive development plans in the first decade of

5 These growth rates are the annualized monthly growth rates for the period January 2005April 2019, estimated from a regression of the form: $\ln X=a+b^{*} t+e t$, where $X$ is production, $t$ is time, and $a$ and $b$ are estimated coefficients.

6 As discussed in Chapters 12-14, these growth linkages are indeed substantial and will likely have a larger effect on overall GDP growth as the share of agricultural crops that is marketed increases. 


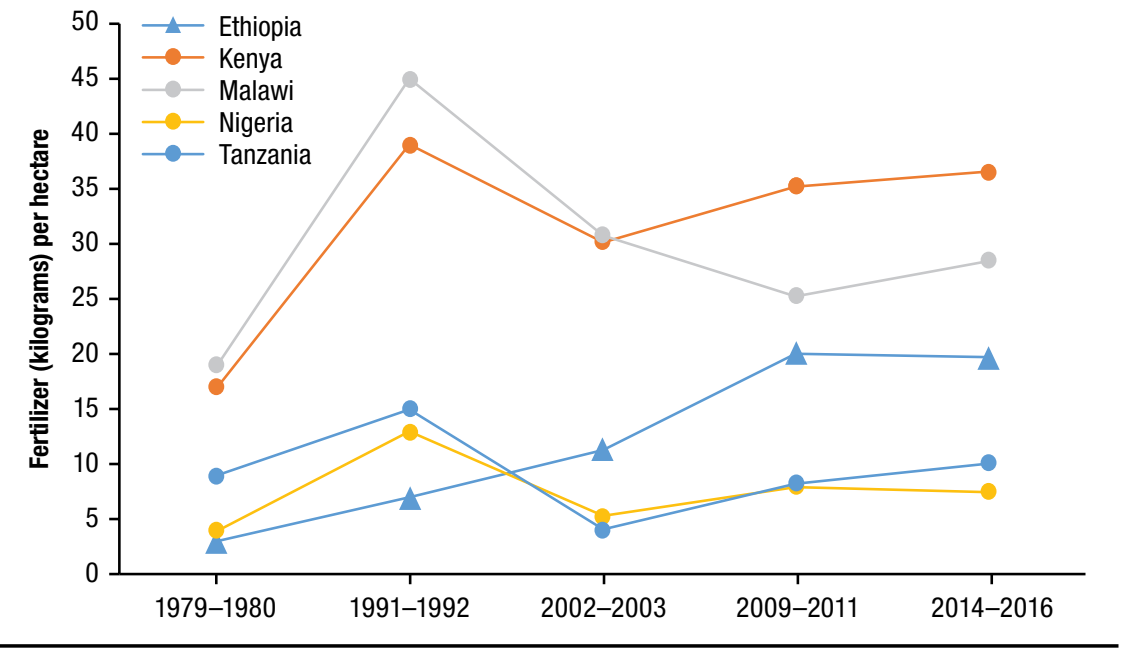

Source: Authors' calculations from FAO (2019).

\section{FIGURE 1.4 Maize yields in selected African countries}

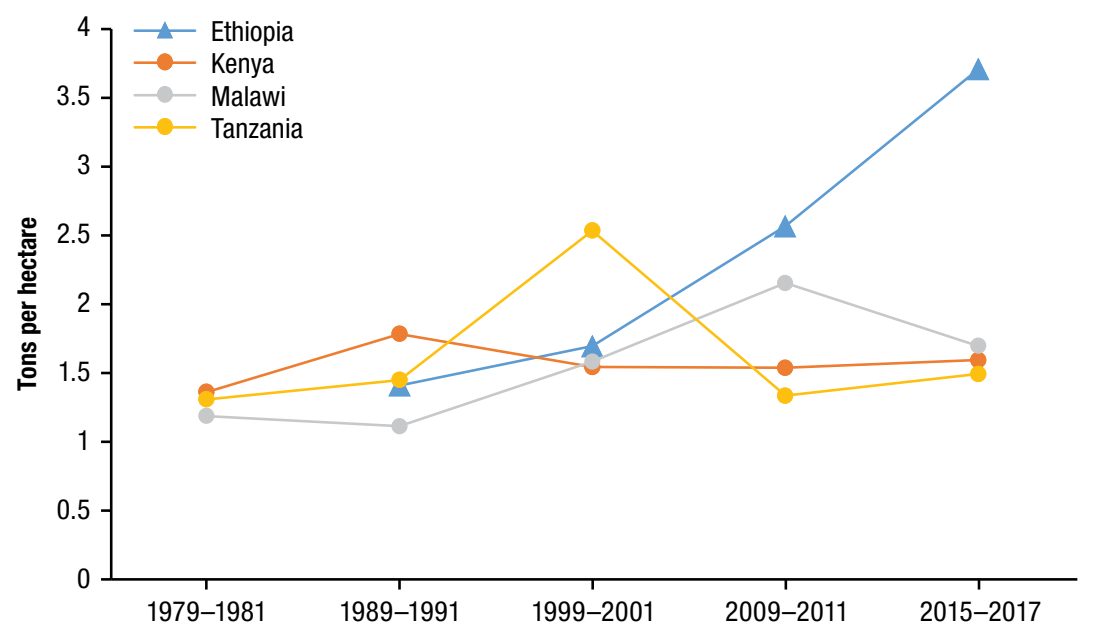

Source: Authors' calculations from FAO (2019). 


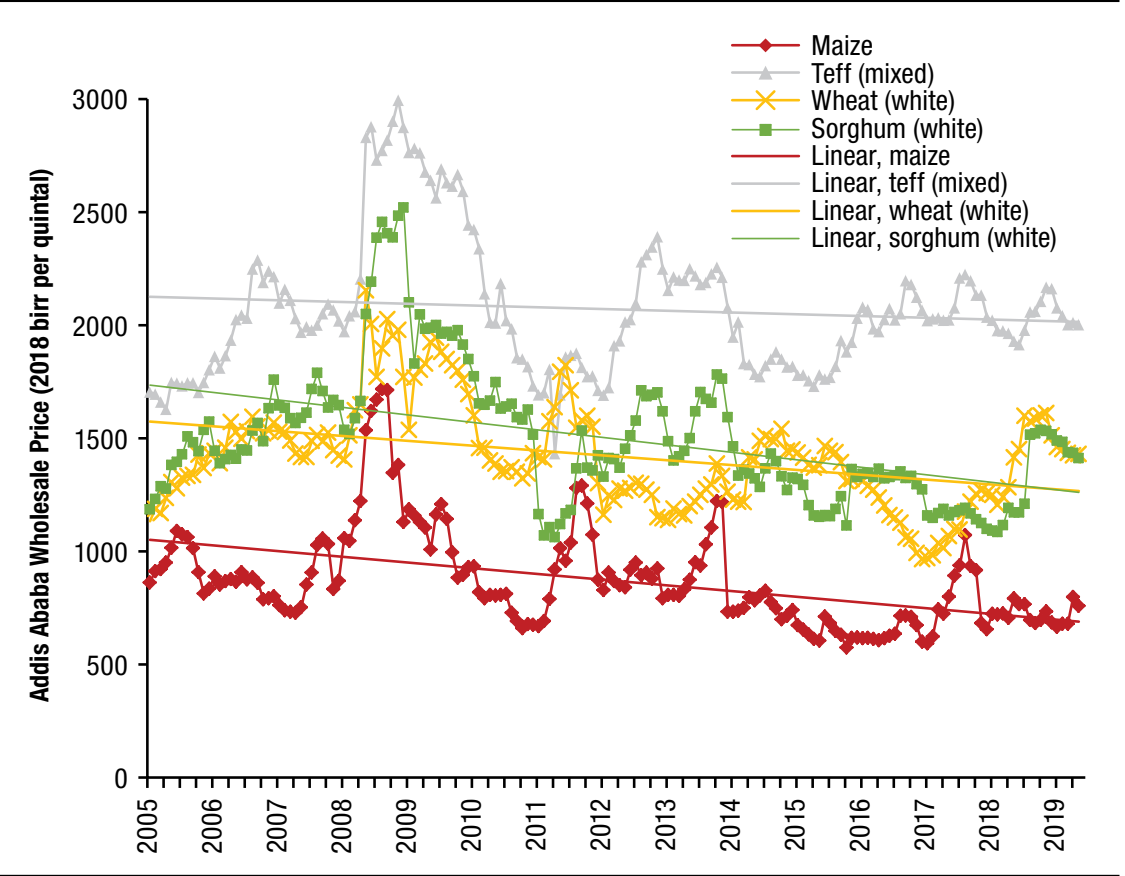

Source: Authors' calculations from EGTE (2019), IMF (2019), and Ethiopia, CSA (2019) data.

the 2000s, the Sustainable Development and Poverty Reduction Program (Ethiopia, MoFED 2002) and the Plan for Accelerated and Sustained Development to End Poverty (PASDEP) (Ethiopia, MoFED 2006), likewise placed a major emphasis on public investment in agriculture. Ethiopia also participated in the Comprehensive Africa Agriculture Development Programme (CAADP), pledging to invest at least 10 percent of its government budget resources in agriculture, a level the government exceeded both before and after the signing of the CAADP Compact in 2009 (Benin 2014). ${ }^{7}$ This investment included major expenditures on rural roads that reduced transport costs and improved market connectivity (Chapter 13). The government also financed a massive increase in fertilizer imports and an expansion

7 Moreover, to address the needs of its most vulnerable population, since 2005, Ethiopia has successfully implemented a large-scale safety net program - the Productive Safety Net Program (PSNP), the biggest safety net in Africa except for South Africa. In 2018 the PSNP covered almost eight million direct beneficiaries. This safety net is generally viewed as a model in Africa as it has helped in significantly improving food security in the country (Berhane et al. 2014). 
in agricultural extension services, including delivery of improved seeds (Chapter 3).

The most recent five-year plans, Growth and Transformation Plans (GTP) I and II, place far less emphasis on agriculture (Ethiopia, MoFED 2010; NPC 2016). Investment in agriculture nonetheless remained substantial (see Figure 13.1). Moreover, as discussed in detail throughout this book, the agricultural sector has continued to perform well, with agricultural GDP growth of 5.2 percent from 2011 to 2016 under GTP I and more than 4 percent from 2016 to 2018 in the first two years of GTP II. ${ }^{8}$ Nonetheless, growth of agricultural GDP has slowed down from its average of 7.8 percent from 2006 to 2011. Meanwhile, total GDP growth remained nearly the same: an average of 10.7 percent per year from 2006 to 2011 and 9.9 percent per year from 2010 to 2015, before slowing to only 5.4 percent per year from 2015 to 2018 .

The agricultural sector faces daunting challenges, however, including increasingly binding land and water constraints in large parts of the country (Chapter 2), possible limits to economically achievable crop yields, and rising rural wage rates (Chapter 11) as workers shift from agricultural to nonagricultural employment and from rural to urban locations. ${ }^{9}$ There is also a major concern in the country on increasing food import dependency. Food imports include most importantly wheat, rice, palm oil, and sugar. Wheat is often provided in the form of food aid for emergency aid (recently linked to a large number of internally displaced persons) or for food safety net programs (the Productive Safety Net Program). Figure 1.6 (left side) shows the evolution of the value of those imports in the country, illustrating a significant increase since 2006. In per capita terms wheat imports have not increased that much (right side); the high peak in 2016 reflects the increased food aid for the major drought during that year. Moreover, export earnings from agriculture have also increased during that period and are in value terms higher than agricultural imports.

The focus on rapid nonagricultural growth and employment in Ethiopia's development strategy under the GTP II is consistent with the normal pattern of economic development. Nonetheless, the experience of other developing countries suggests that substantial agricultural growth will also be required, especially to promote equity and accelerate poverty reduction. Investments

8 Throughout this book we adopt the convention of referring to an Ethiopian fiscal year (approximately from September 1 to the following September 1) by the second calendar-that is, 20172018 is denoted as 2018 .

9 This rise in real wages is a measure of success for the rural sector overall but may slow future agricultural growth. 
FIGURE 1.6 Value of major agricultural imports (left) and wheat imports per capita (right)
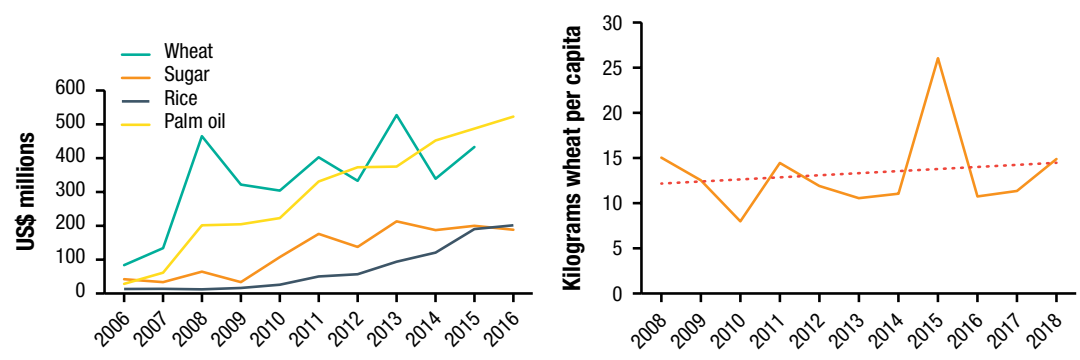

Source: UN Statistics Division (2019), USDA (2019), and World Bank (2017).

will be needed throughout Ethiopia's agrifood system - that is, all the sectors, actors, and activities involved in agriculture and providing food for the country's population, including input supply, food processing, transport, marketing, and retail sales of food by restaurants, shops, and street vendors.

\section{Objectives of This Book}

This book presents a forward-looking analysis of Ethiopia's agrifood system in the context of a rapidly changing economy. The overarching focus is to understand past trends based on solid and large-scale national representative data and to analyze the pattern of transformation unfolding in Ethiopia's agrifood system and its economy more broadly. We touch on a number of challenges for each of the issues studied. In some of the chapters we look at future scenarios by doing explicit modeling of the future or by putting Ethiopia in an international context to benchmark where Ethiopia might be in comparison with some of these other countries that are in a more advanced stage.

The analysis is based on substantial empirical research using satellite data on land use, official national surveys of agricultural production and household expenditures, and other household, firm, and trader data collected by IFPRI and national researchers. Alternative future scenarios are analyzed using an economywide model to simulate the impacts of changes in technology, urbanization, and economic structure to 2040. Overall, the book builds on several earlier volumes chronicling the evolution of Ethiopia's agricultural sector and food policy, including People of the Plow (McCann 1995), Famine and Food Security in Ethiopia (Webb and von Braun 1994), and Food and Agriculture in Ethiopia: Progress and Policy Challenges (Dorosh and Rashid 2012). 


\section{Contributions to the Literature}

This book contributes to the literature in four main ways. First, it further documents and extends the story of successful agricultural development in Ethiopia, one of the largest countries in Africa. Since the aforementioned volumes were written, the microlevel data on agriculture and food security has been greatly enriched by additional rounds of the Agricultural Sample Surveys, surveys fielded to analyze the impact of the Agricultural Growth Program and the Feed the Future program of USAID, satellite data, the Household Income and Expenditure Survey as well as price surveys done by Ethiopia's Central Statistical Agency (CSA), enabling a richer analysis of key issues.

Second, the book looks at the agrifood system as a whole by going beyond crop agriculture alone and by including analysis of off-farm activities linked to the agricultural sector, such as input marketing and food trading, logistics, processing, and retailing. We also document the transformation that is happening in the rural nonfarm economy and elaborate on the important livestock sector and the functioning of its markets.

Third, this book explicitly covers the impacts of changes in key aspects of Ethiopia's economy outside of the agrifood system, such as rapid urbanization and the broader structural transformation of the economy. It is also broader in scope than recent work on individual crops, such as The Economics of Teff (Minten, Taffesse, and Brown 2018).

Fourth, the focus on future scenarios is on the medium run as well as the short run. Earlier analyses, such as the analysis done for CAADP showing that continued investments would spur agricultural output growth, and assuming moderate overall income growth in the economy, led to a sharp reduction in poverty, focused on shorter periods (for example, from 2005 to 2015 in both Diao et al. [2012] and Dorosh and Thurlow [2012]). The analysis in this book focuses on the near term but also includes analysis out to 2040, highlighting how major changes in Ethiopia's economy over time will affect the relative poverty-reduction effects of agriculture, the agrifood system, and nonagricultural investments.

\section{Agricultural Growth and Structural Transformation}

Structural transformation, an increase in the shares of nonagricultural sectors in GDP and in employment, is a central objective of Ethiopia's development 
FIGURE 1.7 Share of different sectors in Ethiopia's economy, 2006/2007-2017/2018 (\%)

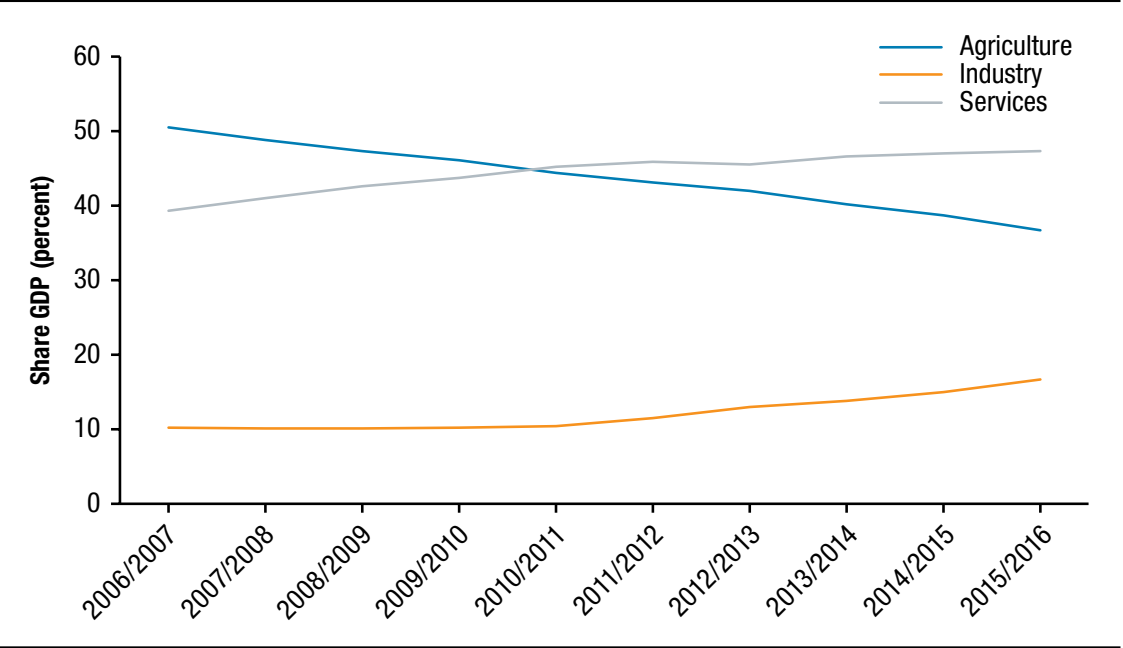

Source: NBE (2019), adjusted by authors for the rebasing of 2015/2016.

strategy. ${ }^{10}$ Much progress has in fact been achieved. As shown in Figure 1.7, the share of nonagriculture in total GDP rose from 53.9 percent in 2009/2010 (the year before the start of GTP I) to 62 percent in $2014 / 2015 .{ }^{11}$ In the first year of GTP II (2015/2016), this share rose by a further 2 percentage points. Likewise, data from the Labor Force Surveys of 2005 and 2013 indicate that the share of nonagriculture in the labor force increased from 19.8 percent to 23.6 percent, a rate of 0.45 percentage points per year. This rate of structural change is significantly slower than the rate observed over the 1993-2013 period (about 0.8 percentage points per year), or in China during the period in

10 These two basic measures of structural transformation are used in Ethiopia's Growth and Transformation Plans. There is a substantial economics literature on structural change. Early work by Johnston and Mellor (1961) argued that agricultural productivity growth is a primary driver of structural transformation through both backward and forward growth linkages (see also Timmer 1988; Mellor 1995; and Gollin, Jedwab, and Vollrath 2016). An alternative view is that economic growth is driven by investments and productivity growth in the modern or industrial sector (Lewis 1954) and the falling shares of agriculture in the labor force and in value-added result to a large extent from more rapid exogenous productivity growth in these nonagricultural sectors. Movement of labor from (lower productivity) agriculture to (higher productivity) nonagricultural sectors results in overall income growth, but a shift of labor into some low productivity service sectors may actually result in lower overall incomes. See Rodrik et al. (2016) and the discussion in Chapter 12, Rodrik, McMillan, and Sepúlveda (2013).

11 Note that the nonagricultural sector includes upstream (for example, production of fertilizer and pesticides) as well as downstream (for example, processing, transport and sales of agricultural commodities) activities. 
FIGURE 1.8 Rates of structural change in selected countries and time periods (\%)

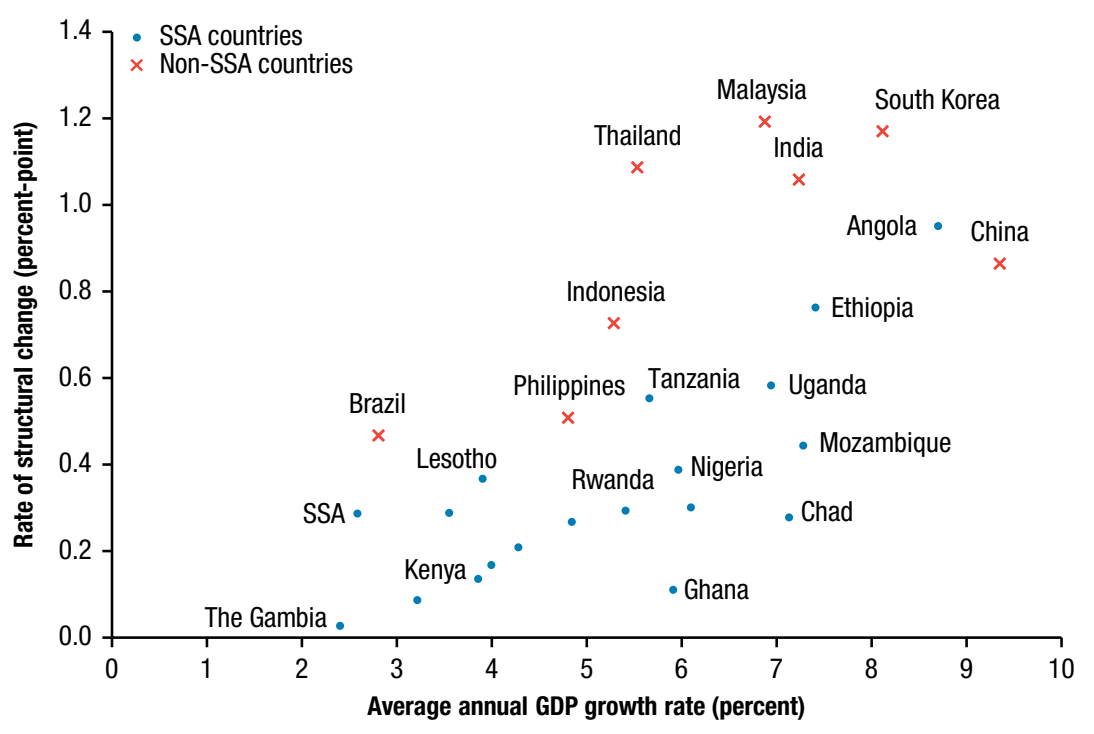

Source: Annex Figure A.1.Thurlow, Dorosh, and Davies (2018) using employment data from ILO (2017) and GDP data from World Bank (2017).

Note: Rate of structural change is the annual percentage point increase in the share of nonagricultural employment in total employment. All SSA countries (Africa south of the Sahara) are for 1993 through 2013. Non-SSA countries analysis is for different time periods: China (1994-2005), Indonesia (1985-2012), South Korea (1980-2000), Malaysia (1988-2001), Philippines (1999-2012), Thailand (1980-2010), India (1980-2010), and Brazil (1981-2011).

which its real GDP was at a similar level (Figure 1.8). Nonetheless, Ethiopia's real GDP growth rate of about 7.5 percent in the 1993-2013 period, and about 9 percent in 2016 has been substantial (about 7 percent per capita). Only China has achieved similar sustained high rates of structural change and real GDP growth.

There are indications that future growth may not be as rapid, however. Much of the growth in the Ethiopian economy in recent years has been due to increased investments financed by unsustainable foreign capital inflows that grew at 36.2 percent per year from 2010/2011 through 2015/2016 (Figure 1.9). Combined foreign and domestic borrowing in this period contributed to a surge in Ethiopia's total foreign and domestic debt, which reached 60.3 percent of GDP in 2016/2017 (Figure 1.10). Thus there is a strong likelihood that the pace of growth and structural change will decelerate in the coming decade. Even with a slowdown in the macroeconomy, though, increased population, urbanization, electrification, improved transport, and growth in per capita incomes are likely to lead to a rapid expansion of the agrifood system. 


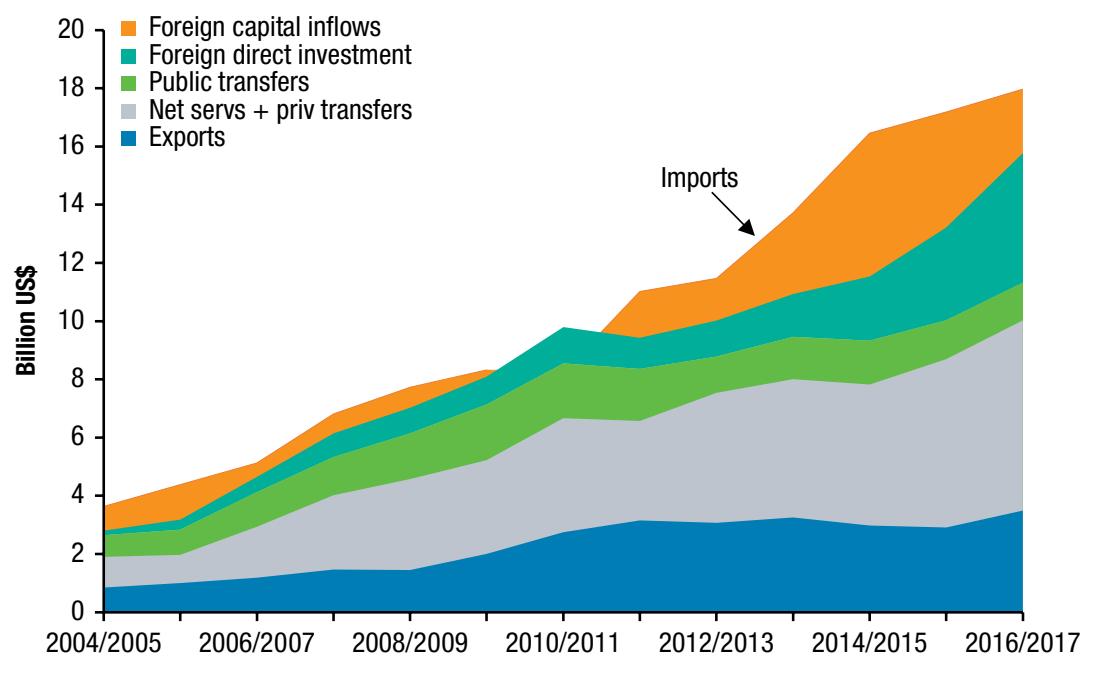

Source: IMF (various years) and authors' calculations.

FIGURE 1.10 Domestic and foreign debt, 2010/2011-2015/2016 (US\$ billions)

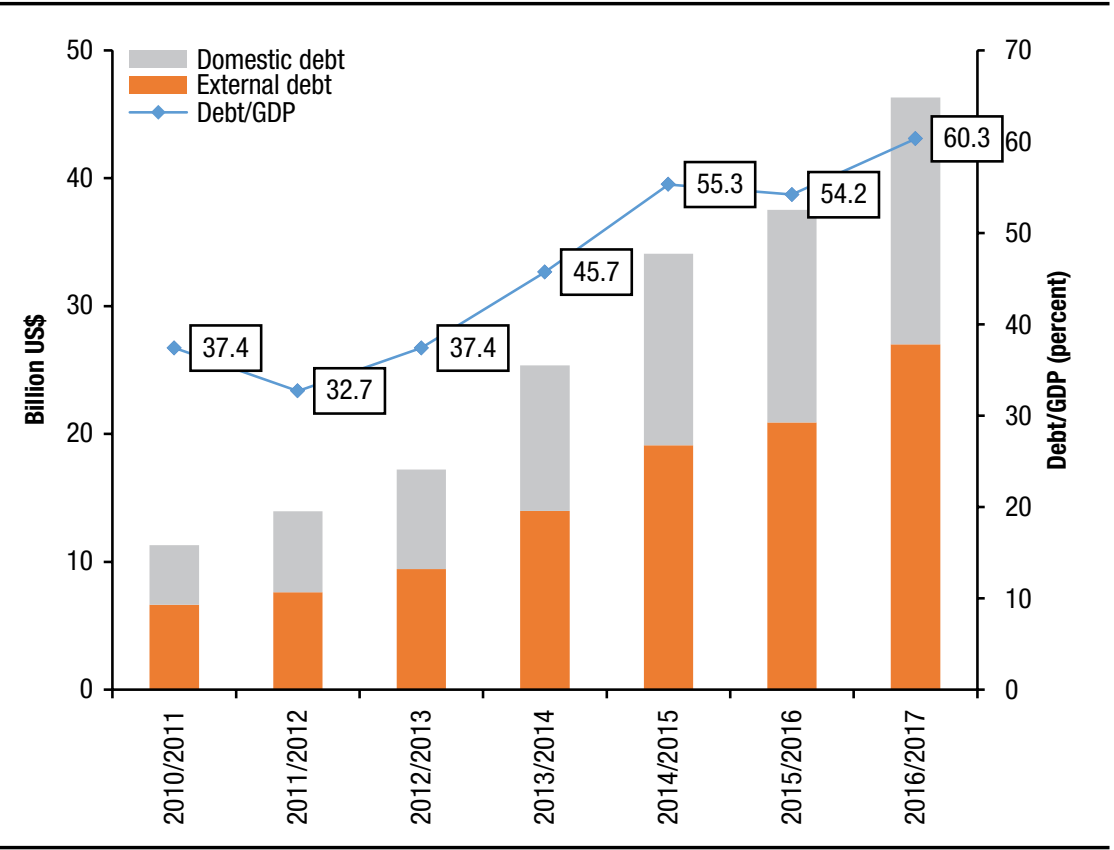

Source: IMF (various years) and authors' calculations. 


\section{Plan of the Book}

This book is structured according to the major components of Ethiopia's agrifood system and their links to the overall economy. The first part, "Natural Resources and Production," presents an analysis of the drivers of recent increases in crop and livestock production. These chapters explore the question of whether such rapid growth can continue in the face of natural resource constraints and climate change. In the second part, "Evolving Markets and Household Consumption," we bring evidence related to how the rapidly changing structure of markets and overall demand will affect Ethiopia's agrifood system. The third part, "Economywide Perspectives," includes an analysis of urbanization and public investments, through simulations of alternative growth and investment strategies, and brings evidence on whether and for how long agricultural and rural development should remain a high priority for public investment in Ethiopia.

These three broad questions (whether rapid growth will continue, how changes in demand will affect the agrifood system, and whether agricultural development should remain a priority) are closely related. If resource constraints become binding, they could potentially slow growth in production and the market transformation process. The result would likely be rising agricultural prices, which would slow the expansion of urban markets, or increased food imports, which would come at the cost of increased producer incomes, thereby limiting positive growth linkages with the nonagricultural economy. Moreover, constraints on agricultural production, whether resulting from agronomic factors, limited market demand, or other considerations, ultimately affect the private and social profitability of investments in agriculture and their potential implications for poverty reduction.

\section{Part 1: Natural Resources and Production}

Chapter 2, "Cropland Expansion," uses spatially disaggregated satellite data to examine changes in land use over time at the national level. This is the first time that such dynamic analysis has been examined at this level. The data indicate a slowing in rate of cropland expansion in much of northern Ethiopia. The authors use results of econometric analysis of land use changes over time to estimate maximum potential economic cropland across space and potential land expansion. The analysis suggests little scope for further crop expansion in the drier parts of the highland but ample opportunities for increased crop cultivation on underused land with sufficient rainfall in parts of western regions (especially Benishangul-Gumuz and Gambella) and in the Oromia region. 
Chapter 3, "Crop Productivity and Potential," documents and explains the causal factors for the rapid expansion in crop production in Ethiopia (official estimates show an increase in production of grain crops from 16.1 million metric tons to 30.6 million metric tons from 2007/2008 to 2017/2018). Using data on input use (such as land, improved seeds, fertilizer, and agricultural extension services), the authors estimate the combined effect of increased inputs. The residual, then, is an estimate of the gains in total factor productivity. Further rapid gains in yields seem less likely, though, given the high levels of input use already achieved. They illustrate some of the challenges in crop production, linked to the research and extension system, the limited access to irrigation, and the seed sector.

Chapter 4, "Climate Change Impacts on Crop Yields," presents results of model simulations of crop yields in Ethiopia through 2085. The analysis draws on climate outcomes from 32 global climate models and an agronomic crop model to estimate effects of expected higher temperatures and, for most of Ethiopia, increased rainfall. The simulation results suggest that climate change will likely have only relatively small effects on average yields of maize, wheat, and sorghum in Ethiopia up to 2055, as agronomic conditions for cultivation of these crops may actually improve in large parts of the country. Nonetheless, crop yields will need to increase over time to enable cereal production to keep pace with expected demand growth due to increases in population and per capita incomes. Moreover, even if future changes in climate have only moderate impacts on average crop yields in Ethiopia, weather outcomes and consequent crop yields are likely to become more variable in the future.

Chapter 5, "Evolving Livestock Sector," shows that livestock is important in Ethiopia’s agricultural economy as almost all farmers own some livestock. Overall livestock output is shown to have grown rapidly over the past decade, estimated at almost 6 percent per year, but about 80 percent of that growth came from increases in the number of livestock. The stock of different livestock species was about 50 percent higher in 2015 than a decade earlier, while modern input use and improvements in production methods contributed little to growth in the livestock sector. Linked to improved access to extension and markets, adoption of improved breeds and improved feeding practices increased, but such adoption patterns started from a very low base. Within the livestock sector, cattle are dominant, making up an estimated three-quarters of the value of livestock stock. However, the share of cattle in total livestock output is declining, and small ruminants are on the rise, especially in pastoralist areas. Given the rapid growth in livestock numbers and the increasing 
livestock density per unit of land, the authors find that feeding practices are changing. Grazing land is declining in availability, so reliance on commercial feed markets is increasing. Access to vaccinations and veterinary service provision have improved, and livestock death rates declined slightly over the past decade. However, the number of livestock lost to deaths is still more than twice the number sold for meat production, indicating important challenges remaining for the development of the livestock sector in Ethiopia.

Chapter 6, "Farm Size, Food Security, and Welfare," looks at the association of farm sizes with food security and welfare. This is an important issue in Ethiopian agriculture given that a growing rural population combined with limited scope for further land expansion and slow movement out of agriculture means that average (mean) farm sizes are decreasing in Ethiopia. Using cross-sectional data for the Ethiopian highlands, the authors find-surprisingly - small differences between owners of small and large farms in key welfare and food security outcomes. For example, a 20 percent increase in owned land area is associated with only a 0.7 percent increase in food consumption (measured in calories). Five adjustments are made by households residing on small farms to assure similar calorie intake as those residing on larger farms. ${ }^{12}$ First, they participate actively in land rental markets and, as a result, are able to double their cultivated land area on average. Second, they compensate their small landholdings with other income sources, mainly livestock and nonfarm businesses, permitting additional food purchases. Third, they cultivate their land more intensively, obtaining higher yields. Fourth, they favor more caloriedense crops that are mostly used for their own consumption. Fifth, they produce as well as consume cheaper food items.

\section{Part 2: Evolving Markets and Household Consumption}

The second part of the book, "Evolving Markets and Household Consumption," begins with Chapter 7 on "Evolving Food Value Chains." Ethiopia's food systems are changing rapidly as high population growth, rapid urbanization, major infrastructure investments, and substantial income growth are leading to dietary, agricultural, and supply chain transformations. Over the past two decades, calorie consumption has risen, the share of starchy staples in the diet has fallen, and the shares of high-value products (such as animal-sourced foods, fruits and vegetables, processed convenience foods, and

12 The analysis in Chapter 6 examines differences in farm and household characteristics across land ownership quintiles, where the mean size of the first and fifth quintiles are 0.25 hectares and 2.93 hectares per household, respectively (see Table 6.1). 
out-of-home food consumption) have risen. At the same time, use of fertilizer, improved seeds, and mechanization is increasing. Nonetheless, smallholders, who have an average agricultural area of 1.0 hectare per holder and who cultivate 93 percent of the agricultural land in Ethiopia, are facing increasing land constraints: farm sizes are declining over time and, in comparison to older farmers, younger farmers are more reliant on land rental markets to access the land that they farm. The transformation of agricultural supply chains is especially rapid, providing for increases in employment. Agricultural commercial surpluses are rapidly growing, and modern food marketing methods and technologies have emerged, including mobile phones, a commodity exchange, and an incipient modern retail sector and food service sector. Domestic markets are better integrated as spatial and seasonal price margins have narrowed. External trade has also expanded since 2000 despite high transport costs and foreign exchange restrictions.

Chapter 8, "Evolving Animal Sourced Foods and Livestock Markets," covers the changing situation in livestock marketing systems. The authors find that in many developing countries in which staple foods dominate the composition of diets, higher consumption of animal-sourced foods (ASF) is associated with significant nutritional benefits. Given the importance of prices for consumption decisions in these settings, they analyze ASF price patterns, relying on a large-scale price dataset collected in 116 urban retail markets in Ethiopia. The authors document important seasonal and spatial patterns, and they find, worryingly, that real prices of ASF have been increasing over the past decade by between 32 percent and 36 percent for three major ASFsmilk, eggs, and meat. Similar price increases are noted in rural and urban areas as well as for tradable and nontradable ASFs. This price trend is in contrast with staple cereals for which real prices stayed at similar levels over the past decade. As they estimate that a price increase of this magnitude would reduce consumption of ASF by approximately 25 percent, holding other things constant, it seems that more investments and attention to the production of ASF and the livestock sector are needed to reduce ASF prices and increase their consumption in Ethiopia.

Chapter 9, "Droughts, Cereal Prices, and Price Stabilization Options," looks at price volatility, causes, and policy options. Increases in cereal prices in Ethiopia often raise concerns about adverse effects for poor net consumers. In particular, the frequent natural calamities-especially droughts-in Ethiopia can lead to important price hikes. But domestic prices of some cereals (especially maize) fluctuate every year with prices at harvest times substantially dropping, to the detriment of producers. Price stabilization efforts are 
therefore an important consideration for Ethiopian policymakers. This chapter sheds light on options for cereal price stabilization in Ethiopia drawing on experiences of other developing countries. The international experience in food price stabilization shows that while some countries have achieved success, the efforts of many others have actually destabilized market prices at great fiscal costs. When assessing the extent to which price stabilization efforts in Ethiopia were effective during the major El Niño-induced droughts of 2015 and 2016 (including food aid distributed through the PSNP), the authors find that an opportunity was missed to enhance food security and consumer welfare by allowing private-sector imports to minimize the rise in cereal prices as well as to reduce the fiscal costs to the government and donors.

Chapter 10, "Food Security," describes the evolution of poverty and food security between 2010/2011 and 2015/2016 and examines the seasonality of food insecurity. Household survey data from 2016 show that Ethiopia continues to face high levels of food insecurity: daily energy consumption is low (3,055 kilocalories per adult on average), and diet quality is poor (starchy staples account for 71.6 percent of calories). There has been relatively little change in the composition of diets between 2011 and 2016, although the diets of the poorest half of the population (especially in rural areas) improved slightly with less reliance on starchy staples and greater dietary diversity. The authors find substantial seasonal patterns, however, with marked variations in energy (calorie) consumption, which is highest in postharvest periods. Regression analysis using the 2015/2016 data reveals that that average energy intake is positively associated with total household expenditure and productive farm assets. The authors find little evidence of diets being affected by rainfall shocks, a notable finding since Ethiopia experienced its worst drought in decades in 2015.

\section{Part 3: Economywide Perspectives}

The third part of the book presents "Economywide Perspectives" on the future of Ethiopian agriculture. Chapter 11, "Nonfarm Income and Rural Labor Markets," examines how the rapid transformation in Ethiopia's economy is affecting off-farm income and labor markets in rural areas. ${ }^{13}$ Data from a large-scale household survey in high potential agricultural areas show that total off-farm income (defined as wage and enterprise income) makes up 18 percent of total rural household income. The shares of off-farm income and

13 The PSNP also contributed to this. Filipski et al. (2016) illustrate the extent to which the PSNP has led to expanded economic activities by illustrating the large spillovers of the program. 
wage income are even larger for the poor and for female- and youth-headed households. Moreover, given strong growth in agriculture and the overall Ethiopian economy, real rural wages have increased by 54 percent since 2006 . While this wage increase is good news for the poor, it also induces adjustments in agricultural production practices, including increased adoption of labor-substituting technologies such as herbicides and mechanization. Higher wages and incomes relax liquidity constraints in the off-season for some households, also contributing to higher productivity.

Chapter 12, "Urbanization and Structural Transformation," describes patterns of urbanization in Ethiopia and government policy to promote development of secondary cities. Official population data indicate rapid urban growth, 4.2 percent per year between 1994 and 2015, far outpacing the overall population growth rate of 2.5 percent. By 2050 urbanization is expected to reach 38 percent with major implications for relative wage rates in rural versus urban areas, infrastructure needs, and public service delivery. Improved road infrastructure is improving connectivity across the country and promoting secondary city development. In addition, recent public investments to promote industrialization and increase manufacturing labor opportunities via newly constructed and planned industrial parks, though small relative to the overall economy, are designed to be a catalyst for future growth.

Chapter 13, "Public Investments and Poverty Reduction," presents results of general equilibrium simulations of the impacts of alternative investment strategies, focusing on national income (GDP) and incomes of the poorest 40 percent of the population in both rural and urban areas. These simulations, which incorporate the major factors discussed in this book-including land constraints, productivity growth, migration, expanding markets, rising incomes and consumption, and greater urbanization-show that although urban investments generate faster economic growth and structural transformation, investments in the rural economy are likely to continue to be more pro-poor than urban public investments through the mid-2020s. After the mid-2020s, investments in cities become more pro-poor. The authors show that though rapid economic growth and structural transformation have diminished the relative importance of the agricultural sector in Ethiopia's economy, continued public investments in agriculture and the broader agrifood system remain crucial for equity and poverty alleviation (and for a reduction of food import dependency) in Ethiopia.

Finally, Chapter 14, "Toward a Medium-Term Agricultural and Rural Development Strategy," highlights the book's major themes and discusses implications for policy. In particular, the authors emphasize the importance of 
continued investments to increase agricultural productivity, market efficiency, and infrastructure (roads, small-scale irrigation, and electricity generation) to support both agriculture and the rural and small-town nonfarm economy. Without these investments substantial poverty increases and growing inequality are likely to result, even if there is rapid overall economic growth.

\section{References}

Bachewe, F. N., G. Berhane, B. Minten, and A. S. Taffesse. 2018. "Agricultural Transformation in Africa? Assessing the Evidence in Ethiopia." World Development 105 (c): 286-298.

Benin, S. 2014. "Implementation Performance and Progress towards Core CAADP Targets." Paper presented at the ReSAKSS annual conference, Addis Ababa, Ethiopia, October 8-10.

Berhane, G., D. O. Gilligan, J. Hoddinott, N. Kumar, and A. S. Taffesse. 2014. “Can Social Protection Work in Africa? The Impact of Ethiopia's Productive Safety Net Programme.” Economic Development and Cultural Change 63 (1): 1-26.

Diao, X., J. Thurlow, S. Benin, and S. Fan, eds. 2012. Strategies and Priorities for African Agriculture: Economywide Perspectives from Country Studies. Washington, DC: International Food Policy Research Institute (IFPRI). http://dx.doi.org/10.2499/9780896291959.

Dorosh, P. A., and S. Rashid. 2012. Food and Agriculture in Ethiopia: Progress and Policy Challenges. Philadelphia: University of Pennsylvania Press. http://ebrary.ifpri.org/utils/ getfile/collection/p15738coll2/id/127347/filename/127558.pdf.

Dorosh, P., and J. Thurlow. 2012. "Implications of Accelerated Agricultural Growth for Household Incomes and Poverty in Ethiopia: A General Equilibrium Analysis." In Food and Agriculture in Ethiopia: Progress and Policy Challenges, edited by P. A. Dorosh and S. Rashid, 219255. Philadelphia: University of Pennsylvania Press.

EGTE (Ethiopian Grain Trade Enterprise). 2019. Commodity Statistics. Accessed September 4, 2019. www.egte-ethiopia.com/en.

Ethiopia, Central Statistical Agency (CSA). 2019. Unpublished market price data.

Ethiopia, Central Statistical Agency (CSA), and ICF International (ICF). 2016. Ethiopia Demographic and Health Survey 2016. Addis Ababa: CSA; Rockville, MD, US: ICF.

Ethiopia, MoFED (Ministry of Finance and Economic Development). 2002. Ethiopia: Sustainable Development and Poverty Reduction Program, Ministry of Finance and Economic Development (MoFED). Addis Ababa.

-2006. Ethiopia: Building on Progress - A Plan for Accelerated and Sustained Development to End Poverty (PASDEP) (2005/06-2009/10), Volume 1: Main Text. Addis Ababa. 
.2010. Growth and Transformation Plan II (GTP II) (2010/11-2014/15), Volume 1: Main Text. Addis Ababa.

FAO (Food and Agriculture Organization of the United Nations). 2019. "Value of Agricultural Production." Accessed September 9, 2019. www.fao.org/faostat/en/\#data/QV.

Filipski, M., J. E. Taylor, G. A. Abegaz, T. Ferede, A. S. Taffesse, and X. Diao. 2016.

Synopsis: Economy-wide Impacts of the Productive Safety Net Programme (PSNP). Ethiopia Strategy Support Program (ESSP) Research Note 57. Addis Ababa: IFPRI.

Gollin, D., R. Jedwab, and D. Vollrath. 2016. “Urbanization with and without Industrialization.” Journal of Economic Growth 21 (1):35-70.

ILO (International Labor Organization). 2017. “Employment Statistics.” Accessed July 5, 2019. www.ilo.org/ilostat.

IMF (International Monetary Fund). 2011. The Federal Democratic Republic of Ethiopia: Poverty Reduction Strategy Paper: Growth and Transformation Plan 2010/11-2014/15Volume 1. IMF Country Report 11/304. Washington, DC. www.imf.org/external/pubs/ft/ scr/2011/cr11304.pdf.

- 2012. The Federal Democratic Republic of Ethiopia 2013 Article IV Consultation. IMF Country Report 12/287. Washington, DC.

- 2014. The Federal Democratic Republic of Ethiopia 2014 Article IV Consultation. IMF Country Report 14/303. Washington, DC.

- 2016. The Federal Democratic Republic of Ethiopia 2016 Article IV Consultation. IMF Country Report 16/322. Washington, DC. www.imf.org/external/pubs/ft/scr/2016/ cr16322.pdf.

— . 2019. International Financial Statistics. Accessed September 4, 2019. http://data.imf.org/ regular.aspx?key $=61545850$.

Johnston, B. F., and J. W. Mellor. 1961. “The Role of Agriculture in Economic Development.” American Economic Review (51): 566-593.

Lewis, W. A. 1954. “Economic Development with Unlimited Supplies of Labour.” The Manchester School 22 (2): 139-191.

McCann, J. 1995. People of the Plow: An Agricultural History of Ethiopia, 1800-1990. Madison, US: University of Wisconsin Press.

Mellor, J. W. 1995. Agriculture on the Road to Industrialization. IFPRI. Baltimore: Johns Hopkins University Press.

Minten, B., A. S. Taffesse, and P. Brown. 2018. The Economics of Teff: Exploring Ethiopia's Biggest Cash Crop. Washington, DC: IFPRI. 
NBE (National Bank of Ethiopia). 2019. Statistical Data Series. Accessed September 4, 2019. www .nbe.gov.et/.

NPC (National Planning Commission). 2016. Growth and Transformation Plan II (GTP II) (2015/16-2019/20), Volume 1: Main Text. Addis Ababa, Ethiopia. http://dagethiopia.org/ new/images/DAG_DOCS/GTP2_English_Translation_Final_June_21_2016.pdf.

- 2017. Ethiopia's Progress Towards Eradicating Poverty - An Interim Report on 2015/16 Poverty Analysis Study. Addis Ababa, Ethiopia.

Rodrik, D., M. McMillan, and C. Sepúlveda. 2013. "Structural Change, Fundamentals, and Growth: An Overview." In Structural Change, Fundamentals, and Growth: A Framework and Case Studies, edited by M. McMillan, D. Rodrik, and C. Sepúlveda, 1-38. Washington, DC: IFPRI.

Scheuermann, H., and T. Mészáros. 2017. African Union: Continental Support for Agricultural Transformation in Africa. Eschbom, Germany: Deutsche Gesellschaft für Internationale Zusammenarbeit (GIZ) GmbH.

Thurlow, J., P. Dorosh, and B. Davis. 2018. “Demographic Change, Agriculture, and Rural Poverty." In Sustainable Food and Agriculture, edited by C. Campanhola and S. Pandey, 31-53. London: Academic Press.

Timmer, C. P. 1988. “The Agricultural Transformation.” Handbook of Development Economics (1): 275-331.

UN Statistics Division. 2019. United Nations Commodity Trade Statistics database (COMTRADE). Accessed November 4, 2019. Comtrade.un.org.

USDA (United States Development Agency). 2019. “Agricultural Commodity Prices.” Accessed November 4, 2019. www.index mundi.com/agriculture/?country=et\&commodity=palm -oil\&graph=imports.

Webb, P., and J. von Braun. 1994. Famine and Food Security in Ethiopia: Lessons for Africa. Washington, DC: IFPRI.

World Bank. 2017. World Development Indicators. Accessed August 1, 2019. http://wdi.org. —.2018. World Bank Poverty and Equity Data Base. Accessed August 1, 2019. http:// databank.worldbank.org/data/source/poverty-and-equity\#. 